\title{
Approximating Perfection
}





\section{Approximating Perfection}

A Mathematician's Journey into the World of

Mechanics

Leonid P. Lebedev

Michael J. Cloud

PRINCETON UNIVERSITY PRESS

PRINCETON AND OXFORD 
Copyright (C) 2004 by Princeton University Press

Published by Princeton University Press, 41 William Street, Princeton, New Jersey 08540

In the United Kingdom: Princeton University Press, 3 Market Place, Woodstock, Oxfordshire OX20 1SY

All Rights Reserved

\section{Library of Congress Cataloging-in-Publication Data}

Lebedev, L. P.

Approximating perfection: a mathematician's journey into the world of mechanics / Leonid P. Lebedev, Michael J. Cloud.

p. cm.

Includes biographical references and index.

ISBN 0-691-11726-8 (acid-free paper)

1. Mechanics, Analytic. I. Cloud, Michael J. II. Title.

QA805.L38 2004

$531-\mathrm{dc} 22 \quad 2003062201$

British Library Catalog-in-Publication Data is available

The publisher would like to acknowledge the authors of this volume for providing the camera-ready copy from which this book was printed.

This book has been composed in Computer Modern

Printed on acid-free paper. $\infty$

www.pupress.princeton.edu

Printed in the United States of America

10987654321 